\title{
Microecology of Monogenean Gill Parasites of Mormyrus rume Valenciennes, 1847 from Man-made Lake Ayame I, Côte d'Ivoire: The Role of Intrinsic Factors
}

\author{
Kassi Georges Blahoua*, Yedehi Euphrasie Adou, Raphaël N'Doua Etilé, Valentin N'Douba \\ Department of Biological Sciences, Laboratory of Hydrobiology, Faculty of Science and Technology, University \\ of Félix Houphouët Boigny, Abidjan, 22 P.O. Box 582 Abidjan 22, Côte d'Ivoire. \\ *Corresponding Author: Kassi Georges Blahoua, Department of Biological Sciences, Laboratory of \\ Hydrobiology, Faculty of Science and Technology, University of Félix Houphouët Boigny, Abidjan, 22 \\ P.O. Box 582 Abidjan 22, Côte d'Ivoire.
}

\begin{abstract}
The spatial distribution of monogenean species was assessed on the gills of 102 specimens of Mormyrus rume from man-made Lake Ayame I between july 2015 and june 2016. Each gill arch was removed and examined to both quantify the number of parasites and their distribution on the gills. Monogenean species of this fish consisted of Bouixella yaoi, B. gorei and B. koutouani. All species were aggregated within the host population. The distribution of these parasites on the gills did not reveal host side preference. However, there were preferences for the specific gill arches. B. yaoi had a preference for attachment to second and third gill arches, whereas B. gorei tended to settle on the second gill arch. Both parasites, which are their robust sclerified haptorial pieces, accumulate mostly in distal part whereas B. koutouani which is weaker, prefer the proximal part of the gill. The low abundance of species recorded had indicated the absence of the intra specific or inter specific competition on the distribution of monogeneans. The volume of the parasite, the phenotype of the haptor, the respiratory water current and probably the reproduction of the parasites are the principal determinants.
\end{abstract}

Keywords: Monogenea, niche restriction, intrinsic factors, Mormyrus rume, man-made lake Ayame I, Côte d'Ivoire.

\section{INTRODUCTION}

Ectoparasitic monogeneans are essentially fish parasites, most of which infest the skin, gill arches and/or fins. These parasites cause localized hyperplasia, disturbance of osmoregulation and mortality of the host [1-2]. This can also result in secondary infections in the host from viruses, bacteria and fungi [3-4]. These organisms constitute the most ubiquitous and abundant group of helminth parasites in the aquatic environment. In most cases, the monogeneans showed a preference for specific sites of the gill apparatus of their host. These pathogens for example, can be specific for one side of the host, for some arches (or one of their faces), or for some parts of the gill filaments [5]. The microhabitat of gill-living monogeneans has been investigated by many authors [6-12].

Mormyrus rume Valenciennes, 1847 is a commercially important fish distributed along major basins in Sahelo-sudanese in West Africa [13]. This fish is abundant in freshwater in Côte d'Ivoire and contributes significantly to subsistence fishing. Among the riverine populace, it is a delicacy and a source of scarce animal protein and minerals [14-15]. Moreover, its delicious flesh is appreciated by local populations. Despite this economic importance, the gill filaments of this host in the man-made lake Ayame I (Côte d'Ivoire) are parasitized by three monogenean species (Bouixella yaoi Blahoua et al., 2009; B. gorei Blahoua et al., 2009; B. koutouani Blahoua et al., 2009). The ecological aspects of the parasitism of this host by these Ancyrocephalids remain unstudied. In fact, fish parasites form interesting and little-used subjects for studies on communities and their ecology $[16,11,15]$. The aim of this study is to provide information on some ecological of gill monogenean of $M$. rume by examining the spatial structure of gill of $M$. rume in order to reveal the mechanisms that determine the coexistence of these parasites. 


\section{Materials AND Methods}

\subsection{Study Area}

Lake Ayame I is located in southeast Côte d'Ivoire $\left(5^{\circ} 30^{\prime}-6^{\circ} \mathrm{N} ; 3^{\circ}-3^{\circ} 5^{\prime} \mathrm{W}\right)$, and is the oldest hydroelectric dam in the country (Figure 1). The lake was built in 1959 in the river Bia. The reservoir has a mean depth of $10 \mathrm{~m}$ and a mean area of $135 \mathrm{~km}^{2}$ [17]. It rises in Sui (Ghana) and enters Aby lagoon (Côte d'Ivoire). The lake Ayame I level is subject to fluctuations depending on local rainfall and evaporation.

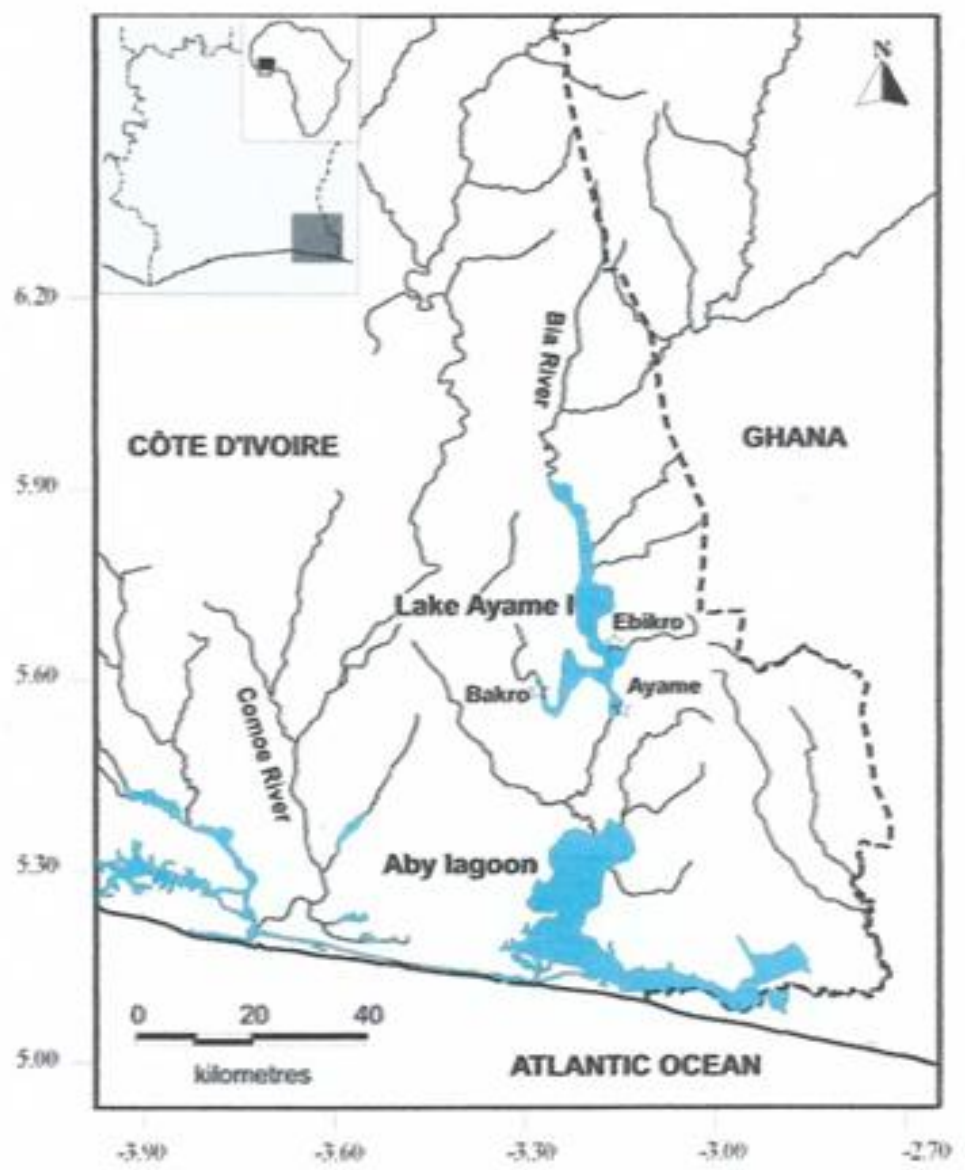

Figure1. Geographical situation of lake Ayamé I (Côte d'Ivoire) and sampling sites (군)

\subsection{Fish Sampling}

Sampling was carried out at the three landings sites between july 2015 and june 2016. One hundred and two specimens of Mormyrus rume were sampled monthly using gillnets. Once caught, the fishes were immediately identified according to the keys given by [18]. After being identified fish, the operculum was removed to expose the gills, which were carefully removed fresh, separated into left and right, and stored in ice $\left(0^{\circ} \mathrm{C}\right)$.

\subsection{Spatial Distribution on Fish Gills}

Gills from the left and right sides of the fish were dissected. The gill arches were numbered I to IV from anterior to posterior. Each arch was divided into three gill segments: dorsal, medial and ventral; two gill areas: proximal and distal (Figure 2). Each gill segment was individually placed in a separate Petri dish with several drops of filtered water and was monitored using a binocular microscope (OLYMPUS SZ 60). Monogeneans were collected and mounted on a slide in a drop of ammonium picrate-glycerine [19]. All species were identified with a microscope magnification of 400 and 1000X, on the basis of available taxonomic characters as described by [20]. Monogeneans identified were counted from each the sectors separately. The position of each individual species was recorded. The dispersion index $\left(\mathrm{S}^{2} / \mathrm{X}\right)$ was used to examine the pattern of aggregation of the species of ectoparasites [21]. 


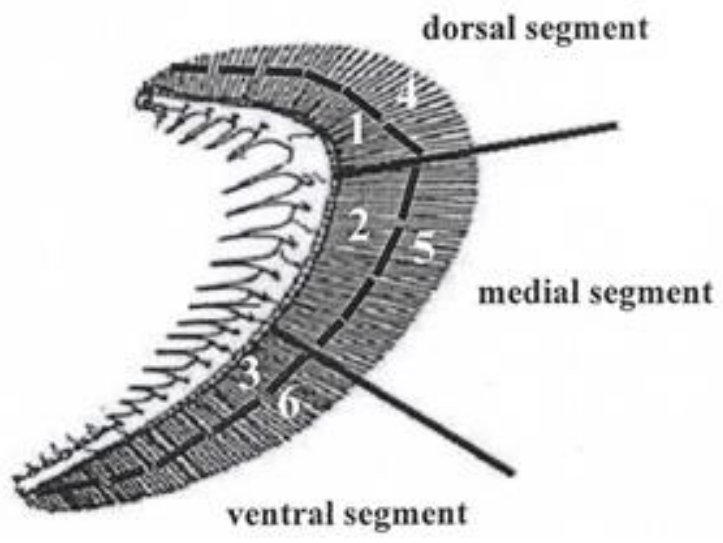

Figure2. Numbering of branchial arch, 1=Proximal-dorsal, 2=Proximal-medial, 3=Proxiaml-ventral, 4=Distal-dorsal, 5=Distal-medial, 6=Distal-ventral

\subsection{Statistical Analysis}

Prevalence and mean intensity were determined according to [22]. The distribution of monogenean species was analyzed by nonparametric statistics tests, Kruskal Wallis ANOVA test, and followed by Mann-Whitney U tests to determine the parasite population differences between the gill arches and between the segments. The Kruskal Wallis (K) test was to compare the intensities of more than two samples. The Mann-Whitney (U) test was used to compare the intensity of infection of two different samples. The Chi square $\left(\mathrm{X}^{2}\right)$ test was used to compare two or more proportions. Differences of $p<$ 0.05 were considered significant. Computations were performed using Statistical Package for Social Science (SPSS) 16.0.

\section{RESULTS}

A total of 102 Mormyrus rume was examined for the presence of monogenean species. Of the hosts infected, 82 (80.39\%) harbored Bouixella yaoi, 79 (77.45\%) harbored B. gorei and $24(23.53 \%)$ harbored B. koutouani (Table 1). The 3064 collected monogeneans comprised 1612 B. yaoi, 1392 B. gorei and $60 \mathrm{~B}$. koutouani. Their low mean intensities of infection were respectively: $19.65 \pm 0.1$, $17.62 \pm 1.2$ and $2.5 \pm 0.4$. The values of variance were $642.75,433.4$ and 10.75. These three species had the typical aggregated pattern of distribution $\left(S^{2}>I M\right)$.

Table1. Prevalence (\%) and mean intensity (MI) \pm SE of Bouixella species of Mormyrus rume

\begin{tabular}{|l|l|l|l|l|l|}
\hline Parasite species & $\mathrm{H}$ & $\mathrm{N}$ & $\mathrm{N}$ & $\mathrm{P}(\%)$ & $\mathrm{MI} \pm \mathrm{SE}$ \\
\hline Bouixella yaoi & 102 & 82 & 1612 & 80.39 & $19.66 \pm 0.1$ \\
\hline Bouixella gorei & 102 & 79 & 1392 & 77.45 & $17.62 \pm 1.2$ \\
\hline $\begin{array}{l}\text { Bouixella } \\
\text { koutouani }\end{array}$ & 102 & 24 & 60 & 23.53 & $2.50 \pm 0.4$ \\
\hline
\end{tabular}

$H$ : number of examined fishes ; $N$ : number of infected fishes ; $n:$ number of parasites ; SE : standard error

\subsection{Distribution of Monogenean Species at the Host Side Level}

The distribution of monogenean species on the right and left gill arches of Mormyrus rume was analyzed (Table 2).

The rate of occupation and mean intensity of Bouixella yaoi, B. gorei and B. koutouani were not statistically different between the right and left side of the host $\left(p>0.05\right.$, respectively $\mathcal{X}^{2}=0.12,0.11$ and 0.03 for the rate of occupation and $\mathrm{U}=4.1,5.6$ and 3.4 for mean intensities).

Table2. Prevalence (\%) and mean intensity (MI) \pm SE of Bouixella species on right and left sides of the gills of Mormyrus rume

\begin{tabular}{|c|c|c|c|c|c|c|}
\hline \multicolumn{7}{|c|}{ Parasite species } \\
\hline & \multicolumn{2}{|c|}{ Bouixella yaoi } & \multicolumn{2}{|c|}{ Bouixella gorei } & \multicolumn{2}{|c|}{ Bouixella koutouani } \\
\hline $\mathrm{P}(\%)$ & 80.39 & 78.43 & 77.45 & 75.49 & 21.56 & 23.52 \\
\hline $\mathrm{MI} \pm \mathrm{SE}$ & $9.89 \pm 0.2$ & $10.01 \pm 0.18$ & $8.71 \pm 0.1$ & $9.14 \pm 0.09$ & $1.4 \pm 0.01$ & $1.21 \pm 0.03$ \\
\hline
\end{tabular}

SE : standard error 
Microecology of Monogenean Gill Parasites of Mormyrus rume Valenciennes, 1847 from Man-made Lake Ayame I, Côte d'Ivoire: The Role of Intrinsic Factors

\subsection{Distribution of Monogenean Species at the Arches Level}

The pattern of gill occupation of the monogenean species of M. rume was shown (Table 3).

Bouixella yaoi mostly occurred on the second and third gill arches and its parasitic load decreased significantly in the anteroposterior direction $(\mathrm{K}=17.03, \mathrm{df}=3, p<0.05)$.

B. gore $i$ was more abundant on the second and first gill arches compared to the other two $(K=21.04$, $\mathrm{df}=3, p<0.05$ ). Parasitic load decreased significantly in the anteroposterior direction.

B. koutouani mostly infected the fourth gill arch. Parasitic load of this species decreased significantly in the posteroanterior direction $(\mathrm{K}=34.04, \mathrm{df}=3, p<0.05)$.

Table3. Prevalence (\%) and mean intensity (MI) \pm SE of Bouixella species on gill arches

\begin{tabular}{|c|c|c|c|c|c|c|}
\hline \multicolumn{7}{|c|}{ Parasite species } \\
\hline \multirow[b]{2}{*}{ Gill arches } & \multicolumn{2}{|c|}{ Bouixella yaoi } & \multicolumn{2}{|c|}{ Bouixella gorei } & \multicolumn{2}{|c|}{ Bouixella koutouani } \\
\hline & $\mathrm{P}(\%)$ & $\mathrm{MI} \pm \mathrm{SE}$ & $\mathrm{P}(\%)$ & $\mathrm{MI} \pm \mathrm{SE}$ & $\mathrm{P}(\%)$ & $\mathrm{MI} \pm \mathrm{SE}$ \\
\hline I & 69.51 & $3.57 \pm 0.01$ & 97.47 & $7.29 \pm 0.3$ & 25 & $1.16 \pm 1.1$ \\
\hline II & 95.12 & $8.51 \pm 0.04$ & 98.73 & $7.66 \pm 0.02$ & 25 & $1.5 \pm 0.2$ \\
\hline III & 98.78 & $8.31 \pm 1.3$ & 74.68 & $3.32 \pm 0.01$ & 20.83 & $1.4 \pm 1.01$ \\
\hline IV & 40.24 & $1.64 \pm 0.5$ & 30.38 & $1.5 \pm 0.2$ & 50 & $3.08 \pm 0.02$ \\
\hline
\end{tabular}

SE : standard error

\subsection{Distribution of Monogenean Species at the Filamentous Zones Level}

The occupation model of the filamentous zone was analyzed (Tables 4 and 5). Bouixella yaoi showed more affinity for the medial and ventral segments $(\mathrm{K}=18.02, \mathrm{df}=3, p<0.05)$ and the distal part of the gill $\operatorname{arch}(\mathrm{U}=9.42, \mathrm{df}=1, p<0.05)$.

B. gorei preferred the medial and ventral segments of the gill arch $(\mathrm{K}=10.05, \mathrm{df}=3, p<0.05)$. This species mostly occurred on the distal part $(\mathrm{U}=6.12, \mathrm{df}=1, p<0.05)$.

B. koutouani was more abundant on the dorsal segment $(\mathrm{K}=4.01, \mathrm{df}=3, p<0.05)$ and the proximal part of the gill $(\mathrm{U}=2.10, \mathrm{df}=1, p<0.05)$.

Table4. Prevalence (\%) and mean intensity (MI) \pm SE of Bouixella species on gill arch segments

\begin{tabular}{|c|c|c|c|c|c|c|}
\hline \multicolumn{7}{|c|}{ Parasite species } \\
\hline \multirow[b]{2}{*}{ Gill segments } & \multicolumn{2}{|c|}{ Bouixella yaoi } & \multicolumn{2}{|c|}{ Bouixella gorei } & \multicolumn{2}{|c|}{ Bouixella koutouani } \\
\hline & $\mathrm{P}(\%)$ & $\mathrm{MI} \pm \mathrm{SE}$ & $\mathrm{P}(\%)$ & $\mathrm{MI} \pm \mathrm{SE}$ & $\mathrm{P}(\%)$ & $\mathrm{MI} \pm \mathrm{SE}$ \\
\hline Dorsal & 78.05 & $3.29 \pm 0.01$ & 81.01 & $2.86 \pm 0.4$ & 100 & $1.88 \pm 0.03$ \\
\hline Medial & 97.56 & $8.73 \pm 0.06$ & 100 & $7.8 \pm 0.02$ & 29.16 & $1.14 \pm 0.1$ \\
\hline Ventral & 100 & $8.57 \pm 0.1$ & 97.46 & $7.7 \pm 0.05$ & 29.16 & $1 \pm 03$ \\
\hline
\end{tabular}

SE : standard error

Table5. Prevalence (\%) and mean intensity $(M I) \pm S E$ of Bouixella species on gill arch parts

\begin{tabular}{|l|l|l|l|l|l|l|}
\hline \multicolumn{7}{|c|}{ Parasite species } \\
\hline & Bouixella yaoi & \multicolumn{3}{l|}{ Bouixella gorei } & \multicolumn{2}{l|}{ Bouixella koutouani } \\
\hline Gill zone & $\mathrm{P}(\%)$ & $\mathrm{MI} \pm \mathrm{SE}$ & $\mathrm{P}(\%)$ & $\mathrm{MI} \pm \mathrm{SE}$ & $\mathrm{P}(\%)$ & $\mathrm{MI} \pm \mathrm{SE}$ \\
\hline Proximal part & 70.73 & $5.06 \pm 0.3$ & 41 & $6.59 \pm 0.08$ & 95.83 & $2.1 \pm 0.01$ \\
\hline Distal part & 97.56 & $16.47 \pm 1.7$ & 100 & $14.95 \pm 1.9$ & 41.66 & $1.2 \pm 0.03$ \\
\hline
\end{tabular}

$S E$ : standard error

\subsection{Mixed Species Infection}

Mixed infections of Momyrus rume were examined with B. yaoi-B. gorei and B. yaoi- B. koutouani combinations (Table 6). 
Microecology of Monogenean Gill Parasites of Mormyrus rume Valenciennes, 1847 from Man-made Lake Ayame I, Côte d'Ivoire: The Role of Intrinsic Factors

Table6. Distribution of Bouixella species on mixed species infections

\begin{tabular}{|c|c|c|c|c|c|c|c|c|}
\hline & \multicolumn{2}{|c|}{ B. yaoi } & \multicolumn{2}{|c|}{ B. gorei } & \multicolumn{2}{|c|}{ B. yaoi } & \multicolumn{2}{|c|}{ B. Koutouani } \\
\hline $\begin{array}{l}\text { Number of } \\
\text { infected host }\end{array}$ & \multicolumn{2}{|l|}{52} & \multicolumn{2}{|l|}{52} & \multicolumn{2}{|l|}{14} & \multicolumn{2}{|l|}{14} \\
\hline \multirow[t]{2}{*}{ Mean intensity } & \multicolumn{2}{|l|}{23.11} & \multicolumn{2}{|l|}{24.06} & \multicolumn{2}{|l|}{16} & \multicolumn{2}{|l|}{2.64} \\
\hline & $\mathrm{P}(\%)$ & $\mathrm{IM} \pm \mathrm{SE}$ & $\mathrm{P}(\%)$ & $\mathrm{IM} \pm \mathrm{SE}$ & $\mathrm{P}(\%)$ & $\mathrm{IM} \pm \mathrm{SE}$ & $\mathrm{P}(\%)$ & $\mathrm{IM} \pm \mathrm{SE}$ \\
\hline Right side & 94.23 & $11.61 \pm 0.1$ & 76.2 & $12.09 \pm 0.3$ & 95 & $7.71 \pm 0.2$ & 91 & $1.54 \pm 0.04$ \\
\hline Left side & 96.3 & $11.5 \pm 0.3$ & 79 & $11.96 \pm 0.1$ & 98 & $8.28 \pm 0.1$ & 93.6 & $1.3 \pm 0.2$ \\
\hline Gill arch I & 68.42 & $2.94 \pm 0.02$ & 92.3 & $9.63 \pm 0.02$ & 66.2 & $1.71 \pm 0.01$ & 23.1 & $0.4 \pm 0.01$ \\
\hline Gill arch II & 96 & $9.25 \pm 0.01$ & 94.5 & $9.54 \pm 1$ & 92 & $6.7 \pm 0.03$ & 21.7 & $0.5 \pm 0.01$ \\
\hline Gill arch III & 98.8 & $9.35 \pm 0.5$ & 72.8 & $3.13 \pm 1.1$ & 97.7 & $7 \pm 1.2$ & 20.2 & $0.46 \pm 0.03$ \\
\hline Gill arch IV & 39.2 & $1.58 \pm 0.02$ & 24.62 & $1.75 \pm 0.01$ & 29 & $0.6 \pm 0.2$ & 88.1 & $1.4 \pm 0.1$ \\
\hline Dorsal segment & 76.2 & $2.1 \pm 0.6$ & 79.74 & $2.63 \pm 0.3$ & 64.6 & $1.64 \pm 0.1$ & 91.3 & $1.84 \pm 0.3$ \\
\hline $\begin{array}{l}\text { Medial } \\
\text { segment }\end{array}$ & 98.4 & $10.52 \pm 1.3$ & 98.9 & $10.61 \pm 0.1$ & 96.8 & $7.36 \pm 0.01$ & 20.8 & $0.53 \pm 0.01$ \\
\hline $\begin{array}{l}\text { Ventral } \\
\text { segment }\end{array}$ & 100 & $10.63 \pm 1.02$ & 94.8 & $10.79 \pm 2.2$ & 99.6 & $7 \pm 1.3$ & 20.7 & $0.46 \pm 0.04$ \\
\hline Proximal part & 73.1 & $43.1 \pm 0.3$ & 38 & $5.08 \pm 0.2$ & 71.3 & $3 \pm 0.03$ & 98.8 & $2.15 \pm 0.3$ \\
\hline Distal part & 95.7 & $18.81 \pm 2.1$ & 100 & $18.98 \pm 1.7$ & 99.4 & $13 \pm 2.2$ & 34.9 & $0.7 \pm 0.01$ \\
\hline
\end{tabular}

Of the 102 examined fish, 52 specimens were simultaneously only infected by B. yaoi-B. gorei (prevalence $=50.98 \%$ ). In these fishes, 1202 B. yaoi and 1251 B. gore $i$ were recorded. Bouixella yaoi predominantly occurred on the second and third gill arches compared with the fourth one $(\mathrm{K}=14.5$, $\mathrm{df}=3, p<0.05)$. This species was more frequently on the medial and ventral segments $(\mathrm{K}=8.23, \mathrm{df}=2$, $p<0.05)$ and the distal part of the gill $(\mathrm{U}=5.40, \mathrm{df}=1, p<0.05)$. Most individuals of $B$. gorei preferred the first and second gill arches $(\mathrm{K}=10.2, \mathrm{df}=3, p<0.05)$. This monogenean was more abundant on the medial and ventral segment $(\mathrm{K}=6.1, \mathrm{df}=3, p<0.05)$ and the distal part $(\mathrm{U}=3.42$, $\mathrm{df}=1, p<0.05)$.

Fourteen specimens were only coinfested by B. yaoi-B. koutouani (prevalence $=13.72 \%$ ). In these fishes, $224 \mathrm{~B}$. yaoi and $37 \mathrm{~B}$. gorei were collected in these infections. Bouixella yaoi was more frequently on the second and third gill arches $(\mathrm{K}=29.71, \mathrm{df}=3, p<0.05)$, on the medial and ventral segments $(\mathrm{K}=178.23, \mathrm{df}=2, p<0.05$. $)$ and on the distal part $(\mathrm{U}=7.45, \mathrm{df}=1, p<0.05)$ whereas $B$. koutouani preferred the fourth gill arch $(\mathrm{K}=15.34, \mathrm{df}=3, p<0.05)$, the dorsal segment $(\mathrm{K}=5.23$, $\mathrm{df}=3, p<0.05)$ and the proximal part $(\mathrm{U}=2.75, \mathrm{df}=1, p<0.05)$.

\subsection{Single Species Infection}

Single species infection of Momyrus rume were analyzed with Bouixella yaoi, B. gorei and B. koutouani (Table 7).

Of the 102 fish examined, 16 hosts (prevalence= 16.69\%) were only infected with 186 B. yaoi. This species predominantly occurred on the second and third gill arches $(\mathrm{K}=7.4, \mathrm{df}=3, p<0.05)$. It preferred medial and ventral segments $(\mathrm{K}=9.22, \mathrm{df}=2, p<0.05)$ and the distal part of the gill $(\mathrm{U}=3.9$, $\mathrm{df}=1, p<0.05)$.

Eight hosts (prevalence $=8.43 \%$ ) were only parasitized with 126 B. gorei. This parasite species preferred the first and second gill arches $(\mathrm{K}=4.8, \mathrm{df}=3, p<0.05)$, medial and ventral segments $(\mathrm{K}=$ 7.28, $\mathrm{df}=2, p<0.05)$ and the distal part $(\mathrm{U}=1.67, \mathrm{df}=1, p<0.05)$.

Eight hosts specimens (prevalence $=8.43 \%$ ) were only harbored 19 B. koutouani. The fourth gill arch was more colonized than the other three $(\mathrm{K}=2.2, \mathrm{df}=3, p<0.05)$. It mostly occupied dorsal segment $(\mathrm{K}=4.71, \mathrm{df}=2, p<0.05)$ and the proximal part of the gill $(\mathrm{U}=1.33, \mathrm{df}=1, p<0.05)$.

\section{DISCUSSION}

This study has underlined a simultaneous colonization of three monogenean species parasitizing the gills of Mormyrus rume from man-made lake Ayame I. In Côte d'Ivoire, fish polyparasitism by monogeneans is quite well documented [20, 16, [23], 11, 15]. This multi-specific parasitism of this fish species could be explained by the permanent presence of vacant niches on its gill biotope. The coexistence of congeneric species in the gill system of $M$. rume allows the exclusion of interspecific 
competition among the factors involved in the structuring of this component community. Indeed, [24] argued that a competition does not permit similar species to coexist. Also, the positive interactions are more frequent between fish ectoparasites of the same host than negative interactions [25]. According to [26], the coexistence is due to the niche heterogeneity, unpredictable recruitment or the aggregated utilization of fragment resources.

Monogenean studied presented an aggregate distribution. In most cases, the parasites are almost universally aggregated between their hosts [27]. This typical distribution pattern in fish parasites could be explained by heterogeneity of the host-parasite relationship [28]. Indeed, the probability for the parasite to meet its host and its chances of surviving in the latter, may vary from one host to another.

The right and left body sides of $M$. rume were similarly infected by monogenean species Bouixella yaoi, B. gorei and B. koutouani. The symmetric distribution of monogenean gill parasites is a welldocumented phenomenon $[10,16,15,12]$. It is suggested that the bilateral symmetric body of this fish and its parasite species support the evenness of the parasite loads of both sides [29, 16].

The mean intensity and prevalence of the core (Bouixella yaoi and B. gorei) species decreased anteroposteriorily from first arch to fourth arch, while for the rare (B. koutouani) species, the parasite load decreased postero-anteriorily. Concerning the variation of the parasite load of the core species, our results coincide with those of [30] for monogenean Mymarothecium boegeri and Anacanthorus penilabiatus from the hybrid patinga on the first three gill arches when compared with fourth gill arch. Similarly, [31] had showed that, on the one hand, the second and third gill arches of Lutjanus guttatus were more infected by Haliotrematoides plectridium and, the other hand, the first and second gill arches were preferred by Euryhaliotrematoides perezponcei. In various other cases, monogenean parasites prefer the two median arches (the second and third one) [32]. This preference is attributed to not only because of the large volume of water flowing through the median arches, but also due to the high number of parasite [33-34]. Differences in colonization surface of gill arches also could influence this preference. In fact, according to [35], the median arches offer large colonization surface to parasites increasing thus the possibility of their invasion by oncomiracidiums. Spatial distribution is thus not due to active choice of attachment site, but rather a result of respiratory current, host fish behavior and habitat use [36]. Concerning the variation of the parasite load of the rare species, our results coincide with those of [37] who showed that Quadriacanthus sp. and Birgiellus kellensis, gill monogeneans of Clarias camerunensis, prefer the fourth gill arch rather the first one. The mode of colonization of Monopisthocotylea larvae could justify this preference [38-39]. Indeed, the infesting larvae settle first on the skin and then migrate towards the gills. Thus, these organisms reach the fourth gill arch and the other three progressively. We also think that the ventilation current of gill filaments only contributes to increase the heterogeneity of sites fixation of parasites. The model exploitation of B. koutouani is posterior-anteriorily therefore contrast with those of [40] with Dactylogyrus nanus et D. micracanthus in Rutilus rutilus.

In Mormyrus rume, Bouixella yaoi and B. gorei mostly parasitized both the distal-medial and distalventral segments of the gill filament, whereas B. koutouani was attached essentially to proximaldorsal segment. Many researchers agreed upon this observation in Cichlid species. [11] found that in Sarotherodon melanotheron, Cichlidogyrus halinus preferred the distal-medial and distal-dorsal halve of the gill arches while $C$. halli distal-dorsal segment. In Tilapia zillii, distal-medial and distal-ventral segments were more colonized by Cichlidogyrus ergensis, while distal-dorsal and distal-medial segments were preferred by $C$. cubitus, $C$. anthemocolpos, $C$. digitatus and $C$. arthracanthus [15]. The size of the sclerified haptorial pieces explains the preferences of site. In fact, the presence of relatively robust haptorial pieces in B. yaoi and B. gorei [20] enables them to live in the zones of high water movement, while B. koutouani with weaker sclerified haptorial pieces [20] are protected from this high force of the ventilation.

This work has indicated that occur the segregation of monogenean gill parasites of $M$. rume. The most abundant monogenean species B. yaoi and B. gorei preferred both the distal-medial and distal-ventral segment of the gill. This spatial niche restriction of Cichlidogyrus may facilitate locating mate. The parasite load of the infracommunities remains weak and thus most niches remain vacant. The 
aggregation of individuals of each parasite species on specific zone and the low parasitic intensities within the gill biotope suggest the absence of interspecific competition (even intraspecific) among these parasites. Similarly, [34] stated since vacant niches are available, interspecific competition is unimportant for freshwater and marine gill parasites of fishes. Indeed, [41], [35] argued that a multispecies infestation cannot be accompanied by competition as long as there is sufficient space and resources.

\section{CONCLUSION}

The study allowed to identify 3 species of monogenean gill parasites of Mormyrus rume. The analysis of their spatial distribution indicated that there was no significant difference in the parasitism of the different gill arches. However, there was an anteroposterior model of accumulation for the majority of the representative of the studied component monogeneans on the arches. No evidence of competition between species of Bouixella on the gill arch was found.

\section{REFERENCES}

[1] Piasecki W., Goodwin A. E., Eiras J. C. and Nowak B. F. (2004). Importance of copepoda in freshwater aquaculture. Zoological Studies 43(2): 193-205.

[2] Bednarska M., Bednarski M., Soltysiak Z. and Polechonski R. (2009). Invasion of Lernaea cyprinacea in Rainbow Trout (Oncorynchus mykiss). ACTA Scientiarum Polonorum Medicina Veterinaria 8(4): 27-32.

[3] Tumbol R. A., Powell, M. D. and Nowak, B. F. (2001). Ionic effects of infection of Ichthyophthirius multifiliis in Goldfish. Journal of Aquatic Animal Health 13: 20-26.

[4] Xu G., Li Y., Zheng W., Peng X., Li W. and Xan Y. (2007). Mineralization of chlorpyrifos by co-culture of Serratia and Trichosporon spp. Biotechnology Letters 29: 1469-1473.

[5] Rohde K. (1979). A critical evaluation of intrinsic and extrinsic factors responsible for niche restriction in parasites. American Naturalist 114(5): 648-671.

[6] Šimkova A., Ondrackova M., Gelnar M. and Morand S. (2002). Morphology and coexistence of congeneric ectoparasite species: reinforcement of reproductive isolation? Biological Journal of the Linneans Society 76: 125-135.

[7] Matejusova I., Simkova A., Sasal P. and Gelnar M. (2003). Microhabitat distribution of Pseudodactylogyrus anguillae and P. bini among and within gill arches of the European eel (Anguilla anguilla L.). Parasitology Research 89: 290-296.

[8] Kadlec D., Simkova A. and Gelnar M. (2003). The microhabitat distrubition of two Dactylogyrus species parasitizing the gills of the barbel, Barbus barbus. Journal Helminthology 77(4): 317-325.

[9] Turgut E., Shinn A. and Wootten R. (2006). Spatial distribution of Dactylogyrus (Monogenean) on the gills of the host fish. Turkish Journal of Fisheries and Aquatic Sciences 6: 93-98.

[10] Sujana M. (2015). Microhabitat distribution of Metazoan parasites on the Gills of L. rohita. Online International Research Journal 5(1): 140-155.

[11] Adou Y. E., Blahoua K. G., Yao S. S and N'Douba V. (2017a). Spatial distribution of two gill monogenean species from Sarotherodon melanotheron Cichlidae in man-made Lake Ayamé 2. Journal of Biodiversity and Environmental Sciences 10(2): 35-44.

[12] Nack J., Massende J. and Messu Mandeng D. F. (2018). Distribution spatiale de deux monogènes du genre Protoancylodiscoides Paperna, 1969 (Dactylogyridea, Ancyrocephalidae) parasites branchiaux de Chrysichthys auratus (Geoffroy Saint-Hilaire, 1808) (Siluriformes, Claroteidae) dans le Lac Ossa (Littoral -Cameroun). Journal of Applied Biosciences 121: 12157-12167.

[13] Bigorne R. (2003). Mormyridae. In: Faune des poissons d'eaux douces et saumâtres de l'Afrique de l'ouest. Tome 1 (Paugy D., Lévêque C. \& Teugels G.G., eds). IRD (Paris), MNHN (Paris), MRAC (Tervuren). pp 155-222.

[14] Gourène G., Teugels G. G., Hugueny B. and Thys Van Den Audenaerde D. F. E. (1999). Evaluation de la diversité ichtyologique d'un bassin Ouest-Africain après la construction d'un barrage. Cybium 23(2): 147160.

[15] Adou Y. E., Blahoua K. G., Etilé R. N., Yao S. S. and N'Douba V. (2017b). Ecological aspects of gill monogeneans of Tilapia zillii (Teleostei: Cichlidae) from man-made Lake Ayamé 2 (Côte d'Ivoire). European Journal of Biotechnology and Bioscience 5(4): 18-28.

[16] Blahoua K. G., Yao S. S., Etilé R. N. and N'Douba V. (2016). Distribution of gill monogenean parasites from Oreochromis niloticus (Linné, 1758) in man-made Lake Ayamé I, Côte d'Ivoire. African Journal of Agricultural Research 11(2): 117-129. 
[17] Laë R. (1997). Estimation des rendements de pêche des lacs africains au moyen de modèles empiriques. Aquatic Living Resources 10: 83-92.

[18] Paugy D., Lévêque C. and Teugels G. G. (2003). Faune des poissons d'eaux douces et saumâtres de l'Afrique de l'Ouest. Tome 1. IRD (Paris), MNHN (Paris), MRAC (Tervuren), 457 p.

[19] Malmberg G. 1957. On the occurrence of Gyrodactylus on Swedish fishes. Swedish, With Description of Species and a Summary in English. Skrifterutgivna av Sodra Sveriges Fiskeriforening pp. 19-76.

[20] Blahoua K. G., Pariselle A., N'Douba V., Koné T. and Kouassi N. J., (2009). Description de trois Monogènes nouveaux parasites branchiaux de Mormyrus rume (Teleostei: Mormyridae) en Côte d'Ivoire. Parasite 16: 51-56.

[21] Shaw D.J. and Dobson A.P. (1995). Patterns of macroparasite abundance and aggregation in wildlife populations: A quantitative review. Parasitology111:S111-S133.

[22] Bush A. O., Lafferty K. D., Lotz J. M. and Shostak A.W. (1997). Parasitology meets ecology on its own terms. Journal of Parasitology 83: 575-583.

[23] Blahoua K. G., Adou Y. E., Etilé R. N., Yao S. S. and N'Douba V. (2018). Occurrence of gill monogenean parasites in redbelly tilapia, Tilapia zillii (Teleostei: Cichlidae) from lobo River, Côte d'Ivoire. Journal of Animal and Plant Sciences 35(3): 5674-5688.

[24] Lim L. H. S. (1990). Freshwater monogeneans of Peninsular Malaysia. Asian Fisheries Science 3: $275-$ 285.

[25] Rohde K. (1994). Niche restriction in parasites: proximate and ultimate cause. Parasitology 109: 69-84.

[26] Morand S., Poulin R., Rohde K., and Hayward C. (1999). Aggregation and species coexistence of ectoparasites of marine fishes. International Journal for Parasitology 29: 663-672.

[27] Poulin R. and Krasnov B. R. (2010). Similarity and variability of parasite assemblages across geographical space. In The biogeography of host-parasite interactions (eds S. Morand \& B. R. Krasnov). Oxford, UK: Oxford University Press. pp. 115-127.

[28] Nering M. B and Zuben C. J. V. (2010). Métodos quantitativos em Parasitologia. Jaboticabal: Funep.

[29] Soylu E., Çolak S. Ö., Erdogan F., Erdogan M. and Tektas N. (2013). Microhabitat distribution of Pseudodactylogyrus anguillae (Monogenea), Ergasilus gibbus and Ergasilus lizae (Copepoda) on the gills of European Eels (Anguilla anguilla, L.). Acta zoologyca Bulgaria 65(2): 251-257.

[30] Jerônimo G. T., Gonçalves E. L. T., Bampi D., Paseto A., De Pádua S. B, Ishikawa M. M and Martins M. L. (2013). Microhabitat of monogenea and copepodids of Lernaea cyprinacea on the gills of four Brazilian freshwater fish. Neotropical Helminthology 7(1): 65-74.

[31] Soler- Jiménez L., Fajer-Ávila E. J. (2012): Microhabitats of dactylogyrids monogenean on the gills of wild spotted rose snapper, Lutjanus guttatus (Steindachner, 1869) from Mazatlán Bay, México. Folia Parasitologica 59: 53-58.

[32] Crafford D., Luus-Powell W. and Avenant-Oldewage A. (2014). Monogenean parasites from fishes of the Vaal Dam, Gauteng Province, South Africa. I. Winter survey versus summer survey comparison from Labeo capensis (Smith, 1841) and Labeo umbratus (Smith, 1841) hosts. Acta Parasitologica 59(1): 17-24

[33] Lo C. M. and Morand S. (2001). Gills parasites of Cephalopholis argus (Teleostei: Serrainidae) from Moorea (French Polynesia): site selection and coexistence. Folia Parasitologica 48: 30-36.

[34] Simková A. and Rohde K. (2013). Community stability and instability in ectoparasites of marine and freshwater fish. Rohde $\mathrm{K}$ ed. The Balance of Nature and Human Impact. Cambridge University Press: Cambridge, pp. 75-87.

[35] Kooskivaara M., Valtonen T. and Vuori K. M. (1991). Microhabitat distribution and coexistence of Dactylogyrus species (Monogenea) on the gill of Roach. Parasitology 104: 273-281.

[36] Blažek R. and Gelnar M. (2006). Temporal and spatial distribution of glochidial larval stages of European unionid mussels (Mollusca: Unionidae) on host fishes. Folia Parasitologica 53: 98-106.

[37] Nack J., Tombi J., Bitja N. A. and Bilong Bilong C. F. (2010). Sites de fixation de deux Monogènes Dactylogyridea parasites branchiaux de Clarias camerunensis : évidence sur le mode d'infestation par les Monopisthocotylea. Journal of Applied Biosciences 33: 2076-2083.

[38] Euzet L. and Combes C. (1998). The selection of habitat among the monogenea. International Journal of Parasitology 28: 1654-1662. 
Microecology of Monogenean Gill Parasites of Mormyrus rume Valenciennes, 1847 from Man-made Lake Ayame I, Côte d'Ivoire: The Role of Intrinsic Factors

[39] Combes C. and Jourdanes J. (2003). Taxonomie écologie et évolution des métazoaires parasites taxonomy ecology and evolution of metazoan parasites. (Livre hommage à Louis Euzet) Tome I. PUP, Perpignan France. pp 161-201.

[40] Bagge A. M and Valtonen E. T (1999). Development of monogenean communities on the gills of roach fry (Rutilus rutilus). Parasitology 118: 479-487.

[41] Buchmann K. (1989). Microhabitat of monogenean gill parasites on European eel (Anguilla anguilla). Folia Parasitologica 36: 321-329.

Citation: Kassi Georges Blahoua et al."Microecology of Monogenean Gill Parasites of Mormyrus rume Valenciennes, 1847 from Man-made Lake Ayame I, Côte d'Ivoire: The Role of Intrinsic Factors" International Journal of Research Studies In Biosciences (Ijrsb), Vol. 7, no. 3, pp. 7-15, 2019. http://Dx.Doi.org/10.20431/ 2349-0365.0703002

Copyright: (c) 2019 Authors. This is an open-access article distributed under the terms of the Creative Commons Attribution License, which permits unrestricted use, distribution, and reproduction in any medium, provided the original author and source are credited. 